\title{
Effects of Youth Unemployment and its consequence: A Survey of Youth in Yobe State, Nigeria.
}

\author{
Galadima. M. \\ Department of Sociology Km 7, Yobe State University Damaturu, Nigeria
}

\begin{abstract}
This study assessed the effect of youth unemployment and its consequence: a survey of Youth in Yobe State, Nigeria. The socio-economic characteristics of respondents were described, the causes as well as the consequence of youth unemployment in the study area were all determined. In order to examine the effect of youth unemployment; all the three senatorial zones of the State were selected; taking one Local Government Area from each zone. Data were collected using well structured questionnaire and analysed through the use of descriptive statistics.From the findings of the research, out of the 160 respondents $51 \%$ were male while $49 \%$ were female with ages ranging from 15 to 65 with an average of 30 years. While $97 \%$ of the respondents were married, whereas, 68\% had formal education, mostly secondary and adult education. Majority of the respondents representing $80 \%$ were non members of cooperative societies and $56 \%$ had no access to credit facilities. The result further showed that, rapid growth of population, growth of labour force arising from rural-urban migration interms of push/pull factors, lack of employable skills, cultural barriers, lack of awareness, lack of vibrant manufacturing sector (industries, factories) and massive corruption were ranked $1^{\text {st }}$, $2^{\text {nd }}, 3^{\text {rd }}$ and $4^{\text {th }}$ respectively as major causes of youth unemployment in the study area. The finding further ranked the consequence of youth unemployment to be $1^{\text {st }}, 2^{\text {nd }}, 3 \mathrm{rd}$ and $4^{\text {th }}$ as; youth as political thugs, youth as a tool for ethno-religious clashes, youth as local militants and youth as an instrument for anti-social vices in the study area. The paper therefore, recommends that, Nigerian Government should play its constitutional role by creating enabling socio-economic and political environment including the provision of infrastructure to make industrial climate investment friendly. Also a package of planned empowerment projects / programme should be put in place, which would massively equip the youth with useful trade and entrepreneurial skills in Automobile, Agricultural production and processing, integrated science clinic, computer and information technology among others.
\end{abstract}

Keywords: Effect, Unemployment, Youth, Empowerment, Democracy.

\section{Introduction}

Generally speaking, unemployment is a global trend, but it however occurs mostly in developing countries of the world Nigeria inclusive, with attendant social, economic, political, and psychological consequences. It is therefore, noted that, massive youth unemployment in any country is an indication of far more complex malaise. The International Labour Organization ILO (2007) report reveals that, the proportions of world's unemployment are steadily increasing and that the number of those without jobs remained at an all time high of more than 195 million, or 6.3 percent, in 2007. For instance, during that period (2007), the Middle East and North Africa were the regions with the highest unemployment rate in the world at 12.2 percent, followed by Sub-Saharan Africa at nearly 10 percent. East Asia's unemployment rate of 3.6 percent remained the lowest. The report affirmed that population growth, especially in South Asia, the Middle East, and North Africa, and SubSaharan Africa, was putting a lot of pressure on job creation. The report concluded that half of all workers in the world - some 1.4 billion working poor - lived in families that survived on less than US \$2 a day per person. These people worked in the vast informal sector - from farms to fishing, from agriculture to urban alleyways without benefits, social security, or healthcare. Some 550 million working poor lived on US \$1 or less per day. In absolute terms, it is estimated that there are about 122 million youths on the African continent (Echebiri, 2005; Chigunta, 2002). Therefore, projections of the population growth into the 21st century indicated that the proportion of youths, in relation to the overall population, will continue to grow. Todaro (1992) in the same manner pointed out that, the high rate of unemployment is a result of continuous transfer of economic activities, especially the youths from rural to urban areas. The presence of large army of unemployed youths in Nigeria is a clear case of failure of leadership to utilize abundant human and natural resources in the country to create jobs that will engage the youths in productive and meaningful economic activities (Adejumobi, 2011).

Moreover, in Nigeria it is a fact that, accurate unemployment rates are difficult to access. Hence, Oyebade (2003) asserted that, Nigeria's unemployment can be grouped into two categories: first, the older unemployed who lost their jobs through retrenchment, redundancy, or bankruptcy; and second, the younger unemployed, most of whom have never been employed. Based on this scenario, it is however, a misplaced 
priority for one to argue that one of the greatest threats to democratic stability and sustenance in Nigeria is the large army of unemployed youths.

In the words of Awogbenle and Iwuamadi (2010), a statistics from the Manpower Board and the Federal Bureau of Statistics indicated that, Nigeria has a youth population of 80 million, representing $60 \%$ of the total population of the country. Also, 64 million of them are unemployed, while 1.6 million are under-employed. Similarly, the 1990-2000 data on youth unemployment showed that the largest group of the unemployed is the secondary school graduates and $40 \%$ of the unemployment rate is among urban youth aged $20-24$ and $31 \%$ of the rate is among those aged 15-19. More so, two-thirds of the urban unemployed are ranged from 15-24 years old. Hence, the educated unemployed tended to be young males with few dependents. There are relatively few secondary school graduates and the lowered job expectations of primary-school graduates. The authors, however, admitted that there is no consistent trend of unemployment rates in Nigeria. An increase in one or two years is sometimes followed by a decline in the subsequent years. But the fact remains that the tree of unemployment is growing progressively in our contemporary Nigeria, except some radical measures are adopted to retard its growth by the deliberate actions and reaction of genuine leaders.

Moreover, the National Bureau of statistics (NBS) in a report titled "2012 National Baseline Survey Report" in collaboration with the federal Ministry of Youth Development, which reveals that more than half, about 54 percent of youth population in Nigeria were unemployed; of this figure, female stood at 51.9 percent compared to their male counterpart, with 48.1 percent unemployed. While NBs must be commended for carrying out and releasing the result of the survey in questioned, the results are indeed humbling. Between the ages of 16 and 64, ignoring those in full time education or those not willing and able to work. The same report equally reveals that, in Nigeria 60 million people available for work, out of this only 48 million Nigerians have jobs (NBS, 2012).

Note to the fact, in the same NBs report the data reveals that, Yobe State in the North Eastern part of Nigeria has the highest level of unemployment among the state in the country with 39 percent unemployment status. Yobe is followed by zamfara and sokoto, with 33.4 percent and 32.4 percent respectively. Lagos state, the country's commercial capital, has the lowest level of unemployment in the country, with an unemployed rate of 7.6 percent (NBS, 2012). This paper therefore, seeks to explore on the effect youth unemployment and its consequence: a survey of youth in yobe state, Nigeria. The objectives was however, made to determine the socio-economic characteristics of respondents in the study area, to identify the causes of youth unemployment and it's consequence in the study area.

\section{Methodology}

The study was carried out in Yobe State. The State is located in the North East zone of Nigeria with its headquarters at Damaturu. It lies between latitude $12000^{\prime} \mathrm{N}$ and longitude $11.300 \mathrm{E}$, covering a land area of about 45,502 square kilometres (km2), with a population of about 2,321,591 people (NPC, 2006).

However, in order to examine the effect of youth unemployment and the way forward: a survey of Youth in Yobe state, Nigeria; all the three senatorial zones of the State were selected; taking one Local Government Area from each zone. The zones include: Northern senatorial zone; Central and South Zone respectively. Hence, to determine the sample size of the population in the study area, a multistage sampling technique was employed to get the respondents. In the first stage, three Local Government Areas were purposively selected in each zone: Bade in Northern zone, Damaturu in Central and Potiskum in South zone, out of the seventeen LGAs in Yobe state, for easy accessibility and to cut across the State. In the second stage, simple random sampling technique was used to select two villages from each Local Government Area, making a total of six villages. Thirdly, $10 \%$ of the population was randomly selected from each village, which form the sample size of (160) of the total population. The data collected were socio-economic characteristics of participants in the study area, causes of youth unemployment and other related periodicals. The collected data were later analyzed using descriptive statistics, involving frequencies and percentages.

\section{Results and Discussions}

This section presents the results and discussion of the data obtained from respondents on their socioeconomic characteristics, which include gender, age, marital status, level of education, employment status, membership of cooperative society and access to credit.

\section{Socio-economic Characteristics of Participants}

From Table 1 the data revealed that $51 \%$ of the respondents were male and $49 \%$ were female. This showed that both gender were adequately represented with little variation in favour of male respondents, which may be as a result of the cultural barrier in the area. The data in Table 1 also, revealed that the age of the respondents ranged between 15 and 65 years with an average of 30 years. This implies that, the respondents are Youth and middle aged and so, still active and can participate adequately in development programmes. It was 
further observed in Table 1 that $97 \%$ of the respondents were married and $3 \%$ were single. This shows that most of the respondents will have greater responsibility than the single, which may encourage respondents to be committed towards their participation in developing themselves. Perez-Morales (1996), noted that there is a trend for rural youth to start having responsibilities at an earlier age than urban youth. Table 1 equally reveals that about $68 \%$ of the respondents had formal education. Such level of education is expected to have positive impact on the respondents' participation in empowerment programmes. The respondents with no formal education were about $32 \%$. This implies that majority of respondents had formal education.

The data also indicates that majority $53 \%$ of the respondents were not employed, $22 \%$ were self employed. While, $25 \%$ were employed in both governmental and non-governmental organizations. The date in Table 1 also reveals that, most of the respondents do not belong to cooperative society. However, Respondents with $4-6$ years of membership duration constitute $20 \%$ while $80 \%$ of the respondents were non members of cooperative society (Table 1). With this level of membership duration, it could be said that majority of the respondents have no experience as members of cooperative group. It was also observed in Table 1 that $56 \%$ of the respondents had no access to credit facilities. While, 44 had access to credit facilities. Ekong (2003) asserts that credit is a very strong factor that is needed to boost both human and enterprise; its availability could determine the extent of production capacity.

Table 1: Socio-economic characteristics of respondents

\begin{tabular}{|c|c|c|c|c|}
\hline Variable & Frequency & Percentages & Mean & \\
\hline \multicolumn{5}{|l|}{ Gender } \\
\hline Male & & 82 & 51.2 & \\
\hline Female & & 78 & 48.9 & \\
\hline \multicolumn{5}{|l|}{ Age (years) } \\
\hline $15-24$ & & 19 & 11.9 & \\
\hline $25-34$ & & 52 & 32.2 & 30 \\
\hline $35-44$ & & 54 & 33.8 & \\
\hline $45-54$ & & 34 & 21.2 & \\
\hline 55-above & & 1 & 0.6 & \\
\hline \multicolumn{5}{|l|}{ Marital status } \\
\hline Married & & 156 & 97.5 & \\
\hline Single & & 4 & 2.5 & \\
\hline \multicolumn{5}{|c|}{ Level of education } \\
\hline No education & & 51 & 31.9 & \\
\hline Adult education & & 21 & 13.1 & \\
\hline Primary & & 34 & 21.2 & \\
\hline Secondary & & 38 & 23.8 & \\
\hline Tertiary & & 5 & 3.1 & \\
\hline Others & & 11 & 6.9 & \\
\hline \multicolumn{5}{|c|}{ Employment Status } \\
\hline Employed & & 40 & 25.0 & \\
\hline Self employed & & 35 & 21.9 & \\
\hline Not employed & & 85 & 53.1 & \\
\hline \multicolumn{5}{|c|}{ Membership of cooperative society (yrs) } \\
\hline Non members & & 80 & 80.0 & \\
\hline $1-3$ & & 00 & 00.0 & \\
\hline $4-6$ & & 20 & 00.0 & \\
\hline $7-9$ & & 00 & 20.0 & \\
\hline \multicolumn{5}{|l|}{ Access to credit } \\
\hline None & & 89 & 55.6 & \\
\hline Access & & 71 & 44.4 & \\
\hline
\end{tabular}

Field survey 2013

\section{Causes of Youth Unemployment in the study Area.}

This section analysed the causes of Youth Unemployment in the study area. Various factors such as rapid growth of population resulting to outstripping supply of jobs in the market, rapid growth of labour force arising from rural-urban migration interms of push/pull factors, lack of employable skills, cultural barriers, lack of awareness, lack of vibrant manufacturing sector (industries, factories) and massive corruption were ranked $1^{\text {st }}, 2^{\text {nd }}, 3^{\text {rd }}$ and $4^{\text {th }}$ respectively. (Table 2) as causes of youth unemployment. This finding agrees with that of Adebayo (1999), Alanana (2003), Awogbenle and Iwuamadi (2010), Ayinde (2008), Echebiri (2005) and Morphy (2008) who equally observed that, the major causes of youth unemployment were among others as rural urban- migration, rapid growth of population, lack of employable skills, lack of vibrant industrial sector and massive corruption were among the causes hindering unemployment of youth. 
Effects of Youth Unemployment and its consequence: A Survey of Youth in Yobe State, Nigeria.

Table 2: Causes of Youth unemployment in the study area.

\begin{tabular}{lccc}
\hline Causes & *Frequency & *Percentages & Ranking \\
\hline Rapid growth of population & 61 & 38.1 & $1^{\text {st }}$ \\
Rapid growth of labour force & 52 & 32.5 & $2^{\text {nd }}$ \\
Lack of employable Skills & 43 & 26.9 & $3^{\text {rd }}$ \\
Massive corruption & 20 & 12.5 & $4^{\text {th }}$ \\
Lack of awareness & 20 & 12.5 & $4^{\text {th }}$ \\
Lack of industries/ factories & 6 & 3.7 & $6^{\text {th }}$ \\
Cultural barrier & 3 & 1.8 & $7^{\text {th }}$ \\
\hline
\end{tabular}

\section{*Multiple responses}

\section{Consequence of Youth Unemployment}

The data in Table 3 indicates that, the use of youth as political thugs is one the major consequence of youth unemployment in the study area, representing $50 \%$ of the respondents. Youth were made to become willing tools in the hand of politicians, to use them for anti-social and dirty political activities .The findings further reveals that, $28 \%$ of the respondents are of the view that, unemployed youth were used as a tool to perpetuate ethno-religious clashes in the study area, which can equally cause a great social upheavals in the country. This agrees with the convictions of (Ibrahim, 2006; Okafor, 2007). The data in Table 3 equally indicates that, $13 \%$ of the respondents were of the view that, unemployed youth were utilised as local militants to attack, destroy properties and lives which affect the socio-economic status of the study area in questioned and Nigeria at large. The result equally shows that, $9 \%$ of the respondents were of the opinion that, youth were used in various anti-social vices such as arson, assault, abduction, stealing, armed robbery, terrorism, sex offences and so on and therefore, this and others has the potential to destabilize and truncate the democratic and development process in the study area and Nigeria at large and the need to adjust.

Table 3, Consequence of unemployed Youth in the study area

\begin{tabular}{lccc}
\hline Consequence & *Frequency & *Percentages & Ranking \\
\hline i. Youth as political thugs & 80 & 50.0 & 1 st \\
ii. Youth as a tool for ethno- religious Clashes & 45 & 28.2 & $2^{\text {nd }}$ \\
iii. Youth as local militants & 20 & 12.5 & $3^{\text {rd }}$ \\
iv. Youth as an instrument for anti- social vices & 15 & 9.3 & $4^{\text {th }}$ \\
\hline
\end{tabular}

\section{*Multiple responses}

\section{Conclusions}

In conclusion, Youth unemployment is considered to be a menace in Nigeria, which constitutes a bottle neck to the democratic and developmental process of our contemporary Nigerian society and particularly Yobe State. This is because; the youths in questioned could be manipulated to undermine the stability of Nigeria's democracy at any point in time. Against this background, there is the need by government at all levels, international community and other stakeholders to embark on massive job creation to take these youths off the streets. Hence, Nigerian leaders should strive to promote good governance in order to engender youth empowerment, employment and socio-economic development in different angle. Thus, based on the findings of the paper it thus recommended that, Nigerian Government must play its constitutional role by creating enabling socio-economic and political environment including the provision of infrastructure to make industrial climate investment friendly. Also a package of planned project should be put in place, which will massively equip the youth with useful trade and entrepreneurial skills in Automobile, Agricultural production and processing, integrated science clinic, computer and information technology among others.

\section{References}

[1]. Adebayo, A. (1999). Youth Unemployment and National Directorate of Employment Self Employment Programmes. Nigerian Journal of Economics and Social Studies, 41(1), $81-102$.

[2]. Alanana, O.O. (2003). Youth Unemployment in Nigeria: Some Implications for the Third Millennium. Global Journal of Social Science, 2(1), 21-26.

[3]. Awogbenle, A.C. \& Iwuamadi, K.C. (2010). Youth Unemployment: Entrepreneurship Intervention Mechanism. African Journal of Business Management,4(6),831-835.

[4]. Ayinde, O.E. (2008). Empirical Analysis of Agricultural Growth and Unemployment in Nigeria. African Journal of Agricultural Research, 3(7), 465-468.

[5]. Chigunta, F, 2002, "The Socio-Economic Situation of Youth in Africa: Problems, Prospects and Options", Paper presented at the Youth Employment Summit, Alexandria, Egypt, September.

[6]. Ekong, E.E. (2003). Introduction to Rural Sociology: An Introduction and Analysis of Rural Nigeria, Uyo, Nigeria: Dave Educational Publishers.

[7]. National Population Commission NPC (2006). Provisional Report for Nigeria. (Draft Report), 2006. 
[8]. Oyebade, S.A. (2003) Education and unemployment of youth in Nigeria: causes, impacts and Suggestions in J.B. Babalola and Adedeji, S.O. (eds) contemporary issue in educational management: book of honour, Ibadan, Nigeria: Department of Educational Management, University of Ibadan, Nigeria Pp. 45-65

[9]. Perez, M.R. (1996). Youth Policy and Resources Related to Rural Youth Programmes. In: Expert Consultation on Extension Rural Youth Programmes and Sustainable Development (FAO), Rome, pp. 101-108.

[10]. Yobe State", Online Nigeria, Accessed on 3 August 2011.http://www.onlinenigeria.com/map. 